www.jmscr.igmpublication.org

Index Copernicus Value: 79.54

ISSN (e)-2347-176x ISSN (p) 2455-0450

crossref DOI: https://dx.doi.org/10.18535/jmscr/v7i6.161

\title{
Study of Antepartal Hemorrhage with Reference to third Trimester Bleeding and its Perinatal Outcome in our Maternity Hospital of Skims Soura
}

\author{
Authors \\ Dr Shazia Nisar ${ }^{1}$, Dr Shahzada Shahid Banday ${ }^{2}$ \\ ${ }^{1}$ Senior Resident Department of Obstetrics and Gynaecology Skims Soura \\ ${ }^{2}$ Senior Resident Department of Neonatal and Paediatric Surgery Skims Soura \\ Corresponding Author \\ Dr Shazia Nisar \\ Senior Resident Department of Obstetrics and Gynaecology Skims Soura, India
}

\section{Introduction}

APH Is defined as bleeding from or into the genital tract from 28 weeks of pregnancy till delivery of baby (end of 2nd stage). 28 weeks is taken arbitrary as lower limit of fetal viability. Incidence of APH is $2-5 \%$ of all pregnancies ${ }^{(1)}$. $\mathrm{APH}$ is grossly classified as

1. Placental bleeding $(70 \%)$ that is further divided into

a. \{placenta previa $35 \%$.

b\{.abruptio placentae $\} 35 \%$

2. Extraplacental (5\%); cervical polp, cervical cancer, varicose veins, local trauma

3. Unexplained (25\%)

In case of APH that is of placental origin bleeding is either following separation of placenta (low lying placenta) implanted in lower uterine segment or from premature separation of normally located placenta ${ }^{(2,3)}$

APH accounts for great toll of maternal mortality and morbidity in India. According to figure in 2013 maternal mortality in India was $17 \%$ and in
Nigeria it was $11 \%^{(4)}$. In this bleeding alone contributes to $75 \%$ cases (includes both APH and PPH), others being raised B.P, complications of delivery and unsafe abortions ${ }^{(5)}$. APH in pregnancy greatly affects perinatal mortality and morbidity because maternal health and newborn health are closely linked to each other. It is found that early neonatal death rate is 3 million annually and 2.6 million babies are still born ${ }^{(6,7)}$ However in recent years due to improvement in medical facilities, early diagnosis, hospitalisation, availability of blood transfusion facilities, liberal use of cesarean section maternal and perinatal mortality and morbidity due to APH has dramatically reduced .

A no.of studies have established risk of placenta previa more with ${ }^{(8,9)}$;

1) Advanced maternal age

2) Multiparity

3) Previous placentae previa

4) Defecient endometrium

5) Multiple pregnancies

6) Smoking 
Risk factors for placental abruption include; increased maternal age, multiparity, low BMI, abruption in previous pregnancy, pre eclampsia, polyhydraminos, intrauterine infections, premature rupture of membranes, abdominal truama, smoking, pregnancy following ART, thromophilias $^{(9)}$

\section{Aims and Objectives}

1) To find the incidence of APH in our study

2) To Study the etiological factors of APH.

3) Perinatal outcome in patients with APH.

\section{Methodology}

It was a prospective study carried in our hospital of Skims soura for a period (Dec 2018- Jan 2019).

It included all antenatal patients with gestational >28 weeks whether booked or unbooked attending our antenatal OPD with history of bleeding $\mathrm{p} / \mathrm{v}$. Total no. of deliveries conducted during this period were 4800 of which 300 cases were APH ,120 cases out of 300 were of third trimester bleed.

\section{Results}

Incidence of APH (third trimester bleed) in our study was: $2.5 \%$

3rd trimester bleed constituted $40 \%$ of total APH cases.

No.of patients with placentae previa $=50(.41 .67 \%)$

No.of patients with abruptio placentae $=70$ $(58.33 \%)$.

Distribution of Patients According to Age

\begin{tabular}{|l|c|c|c|}
\hline $\begin{array}{l}\text { Age } \\
\text { group }\end{array}$ & $\begin{array}{c}\text { Abruptio } \\
\text { placentae }\end{array}$ & $\begin{array}{c}\text { Placentae } \\
\text { previa }\end{array}$ & Total \\
\hline$<20 \mathrm{yrs}$ & $10(14.3 \%)$ & $10(20 \%)$ & $20(16.67 \%)$ \\
\hline $20-30 \mathrm{yr}$ & $35(50 \%)$ & $30(60 \%)$ & $65(54.1 \%)$ \\
\hline $30-40 \mathrm{yr}$ & $25(35.7 \%)$ & $10(20 \%)$ & $35(29.16 \%)$ \\
\hline
\end{tabular}

Thus APH was more in age group of 20-30 yr $(54.1 \%)$

\section{Distribution of Patients according to Parity}

\begin{tabular}{|l|c|c|c|}
\hline Parity & $\begin{array}{c}\text { Abruptio } \\
\text { placentae }\end{array}$ & $\begin{array}{c}\text { Placentae } \\
\text { previa }\end{array}$ & Total \\
\hline Primi & $10(14.2 \%)$ & $10(20 \%)$ & $20(16.67 \%)$ \\
\hline Multi & $50(71.4 \%)$ & $25(50 \%)$ & $75(62.5 \%)$ \\
\hline Grandmulti & $10(14.2 \%)$ & $15(30 \%)$ & $25(20.83 \%)$ \\
\hline
\end{tabular}

Thus APH was more in multiparous (62.5\%)
Distribution of Patients According to Booking Status

\begin{tabular}{|l|c|c|}
\hline Booking status & $\begin{array}{c}\text { Abruptio } \\
\text { placentae(70) }\end{array}$ & $\begin{array}{c}\text { Placentae } \\
\text { previa(50) }\end{array}$ \\
\hline Registered & 25 & 15 \\
\hline Unregistered & 45 & 35 \\
\hline
\end{tabular}

Thus no. of patients attending our OPD were mostly unregistered (80) patients

Distribution of Patients according to mode of Delivery

\begin{tabular}{l|c|c|c|}
\hline $\begin{array}{l}\text { Mode of } \\
\text { delivery }\end{array}$ & $\begin{array}{c}\text { Abruptio } \\
\text { placentae }\end{array}$ & $\begin{array}{c}\text { Placentae } \\
\text { previa }\end{array}$ & Total \\
\hline Vaginal delivery & $48(68.5 \%)$ & $4(8 . \%)$ & $52(43.33 \%)$ \\
\hline Lscs & $19(27 \%)$ & $40(80 \%)$ & $59(49.16 \%)$ \\
\hline C.Hysterectomy & $3(4 \%)$ & $6(12 \%)$ & $9(7.5 \%)$ \\
\hline
\end{tabular}
Thus lscs (49.16\%) was more in APH (3rd
trimester bleed)

Distribution of Patients according to risk factors

Out of 120 patients only 50 patients presented with risk factors

\begin{tabular}{|l|c|c|c|}
\hline Risk factors & $\begin{array}{c}\text { Abruptio } \\
\text { placentae. } \\
(30)\end{array}$ & $\begin{array}{c}\text { Placentae } \\
\text { previa(20) }\end{array}$ & Total(50) \\
\hline Previous lscs & $3(10 \%)$ & $7(35 \%)$ & $10(20 \%)$ \\
\hline $\begin{array}{l}\text { PIH in present } \\
\text { pregnancy }\end{array}$ & $14(46.66 \%)$ & $2(10 \%)$ & $16(32 \%)$ \\
\hline $\begin{array}{l}\text { Previous } \\
\text { abortion }\end{array}$ & $1(3.3 \%)$ & $3(15 \%)$ & $4(8 \%)$ \\
\hline Malpresentation & $1(3.3 \%)$ & $2(10 \%)$ & $3(6 \%)$ \\
\hline Anemia & $6(20 \%)$ & $4(20 \%)$ & $10(20 \%)$ \\
\hline Recurrence & $5(16.6 \%)$ & $2(10 \%)$ & $7(14 \%)$ \\
\hline
\end{tabular}

Thus history of PIH was imp risk factor for abruptio placentae and history of previous lscs was imp risk factor for placentae previa.

\section{Fetal Outcome in Placentae Previa}

\begin{tabular}{|l|c|c|c|}
\hline Parameter & $\begin{array}{c}\text { Term } \\
\text { delivery }\end{array}$ & $\begin{array}{c}\text { Preterm } \\
\text { delivery }\end{array}$ & Total \\
\hline Live births & 22 & 8 & $30(60 \%)$ \\
\hline IUD'S & 6 & 3 & $9(18 \%)$ \\
\hline Stillbirth & 5 & 0 & $5(10 \%)$ \\
\hline $\begin{array}{l}\text { Early neonatal } \\
\text { death }\end{array}$ & 2 & 4 & $6(12 \%)$ \\
\hline
\end{tabular}

Thus perinatal mortality in placentae previa was $40 \%$ 
Fetal Outcome in Abruptio Placentae

\begin{tabular}{|l|c|c|c|}
\hline Parameter & $\begin{array}{c}\text { Term } \\
\text { delivery }\end{array}$ & $\begin{array}{c}\text { Preterm } \\
\text { delivery }\end{array}$ & Total \\
\hline Live births & 32 & 3 & $35(50 \%)$ \\
\hline IUD'S & 17 & 3 & $20(28.57 \%)$ \\
\hline still births & 8 & 0 & $8(2.8 \%)$ \\
\hline Early neonatal death & 2 & 5 & $7(18.57 \%)$ \\
\hline
\end{tabular}

Thus perinatal mortality rate in abruptio placentae was $50 \%$

\section{Perinatal Mortality in Terms of Birth Weight}

\begin{tabular}{|l|c|c|}
\hline Birth weight & Abruptio placentae & Placentae previa \\
\hline$<2.5 \mathrm{~kg}$ & $13(37.14 \%)$ & $12(60 \%)$ \\
\hline $2-2.5 \mathrm{~kg}$ & $8(22.85 \%)$ & $6(30 \%)$ \\
\hline$>2.5 \mathrm{~kg}$ & $14(40 \%)$ & $2(10 \%)$ \\
\hline
\end{tabular}

Thus perinatal mortality is increased with birth weight $<2.5 \mathrm{~kg}$

\section{Discussion}

APH is one of the important obstetric emergencies, a pregnant lady may become exsanguinated within minutes due to vaginal bleeding. That is why APH is regarded alarming and requires evaluation.

Incidence of APH in our study was 2.5\%.This incidence is same as study done by Arora and coworkers from Pondicherry ${ }^{(10)}$.Total no.of cases of APH (third trimester bleed)in our study were 120 ,out of which 70 cases were of abruptio placentae $(58.33 \%)$ and 50 cases were of placenta previa $(41.66 \%)$. Thus abruptio placentae was common cause of 3rd trimester bleed followed by placenta previa. out of 120 patients 40 cases were registered and 80 cases were unregistered. This shows lack of awareness, education and poor antenatal follow up in our Kashmir belt. If we will see that maximum incidence of APH was in age group of 20-30 yr (54.16\%). This was because of highest fertility in age group of 20-30yr. If we will go towards parity we can see that APH was in multigravida (62.5\%). This is similar to study done by S Singhal, $2013^{(11)}$ who also reported increased incidence of APH in multigravida. Incidence of placenta previa increased with age Biro, 2012 ${ }^{(12)}$ Of 120 patients of APH 50 (41.6\%) patients were those that presented with risk factors .History of $\mathrm{PIH}$ in present pregnancy was major risk factor for abruption (46.6\%) while as previous lscs increases the risk of placenta previa and this risk increases with the no.of previous scars. Patients with placentae previa had $15 \%$ association with previous abortion while as in abruption association was only $3.3 \% \mathrm{pIH}$ is major risk factor for abruption. Fetal mortality in abruption is determined by presence or absence of HTN. Another factor for abruption is presence of abruption in previous pregnancy. This was quantified by Ananth and colleagues in tometa analysis $^{(13)}$. Risk of recurrence for abruption in present study was $16.6 \%$ that correlates with Ananth and colleagues ${ }^{(13)}$. Abnormal presentation was seen in $6.6 \%$ of abruption and $10 \%$ of placenta previa. This is because presence of placenta in lower uterine segment prevents engagement. However anemia was a risk factor that was same in abruptio placentae and placentae previa (20\%). This shows low hemoglobin content of antenatal patients of Kashmir belt especially in those who don't have regular antenatal follow up. If we will go for the mode of delivery we will see that $80 \%$ of patients of placenta previa are delivered by lscs while as $68.5 \%$ of patients with abruption were delivered by normal vaginal delivery. cesarean hysterectomy was done in 9 cases of $\mathrm{APH}(7.5 \%)$.

If we have look towards perinatal outcome in placentae previa we can see that live birth rate was $60 \%$ and perinatal mortality was $40 \%$ in which there were 9 IUD'S, they had absent fetal heart sound at the time of admission. Most of these IUD'S were from patients that were referred to our tertiary hospital as unregistered. there were 5 stillbirths and 6 neonatal death's. Most of early neonatal deaths were seen in ICU of paediatric department of Skims soura that were born prematurely and died because of septicemia and intracranial hemorrhage.

In Abruptio placentae live birth rate was 50\% while as there were 20 IUD'S, 8 still births and 7 early neonatal deaths. this high perinatal mortality in Abruptio placentae was because it (abruptio placentae) occurred just at 34- 36 weeks that accounted for increased stillbirths and IUD'S. Early neonatal deaths were because of prematurity. 
If we see perinatal mortality in terms of birth weight it is seen that perinatal mortality increases with decrease in birth weight.(birth weight <, $2.5 \mathrm{~kg}$ ). In Abruptio placentae increased perinatal mortality even with birth weight $>2.5 \mathrm{~kg}$ is explained on account of increased rate of abruption at 34- 36 .weeks ${ }^{(2,8-11)}$

\section{Bibliography}

1. Konje KE, Taylor DJ. Bleeding in late pregnancy.In James DJ, Steer PJ, weiner $\mathrm{CP}$, Gonik B, editors. High risk pregnancy management options,2nd ed. London: Harcourt 2000

2. IaN Donald practical obstetric problems; 7th edition .2014:315

3. Williams obstetrics :F Gary, cunningham, Kenneth J. Leveno, Steven L. Bloom, catherine Y. Spong, jodi S, Dashe, Barbara L. Hoffman, Brian M. Casey, Jeanne S.Sheffield.24th edition:783,801,803.

4. WHO 2014.Trends in maternal mortality: 1990 to 2013.Estimates by WHO, UNICEF,UNFPA. The world bank the united nations population division.

5. Say L etal. Global causes of maternal death :A WHO Systematic analysis Lancet.2014;6(1):e323-33

6. UNICEF, WHO, The world Bank, United Nations population division.The interagency Group for child mortality estimation (UNIGME).Levels and trends in child mortality. Report 2013 .New York, USA, UNICEF,2013.

7. Cousens S, Blencowe H, Stanton C,Chou D, Ahmed S, Steinhardt L, etal. National, regional and worldwide estimates of stillbirth rates in 2009 with trends since 1995: asystematic analysis-- Lancet. 2011;377(9774):1319-30

8. Rasmussen S, Albrechtsen s, Dalaker k. obstetric history and risk of placenta previa .Acta obstet Gynaecol Scans. 2000;79(6):502-7
9. Antepartum hemorrhage (Green top Guidelines No.63)Royal college of obstetricians and amp; Gynaecologists. Available from https://www.rcog.org.uk/en /guidelines research -services /guidelines/gtg63/

10. Arora R, Devi U, Majumdar k.Perinatal morbidity and mortality in antepartal hemorrhage .J.obstet Gynaecol India .2001;51(3):102

11. S Singhal, Nymphaea, S Nanda. Maternal and perinatal outcome in antepartum hemorrhage: A study at Tertiary care referral institute .The international journal of Gynaecology and obstetrics:2013;9(2)

12. Biro MA, Davey MA, Carolan M ,etal. Advanced maternal age and obstetric morbidity for women giving birth in Victoria, Australia:a population based study. Aust NZJ obstet Gynaecol 2012;52 (3):229-34

13. Ananth CV, wilcox Az, Savita DA, Bowes WA, Luther ER. Effect of maternal age and parity on the rise of uteroplacental bleeding in pregnancy. obstet Gynaecol 1996;88:511-6. 